\title{
General systems theory and the operation of basins without an outlet:
}

\section{A methodological aspect}

\author{
Maciej Major \\ Institute of Geoecology and Geoinformation, Adam Mickiewicz University, Dzięgielowa 27, 61-680 Poznań, Poland; \\ e-mail: maciej.major@amu.edu.pl
}

\begin{abstract}
Basins without outlets, often with a small water body at the bottom, are a characteristic element of a postglacial landscape. Areas nourishing those small landforms belong to the passive part of catchments of hydrographic systems and determine the retentivity of entire drainage basins. The most suitable approach to adopt in research on those objects seems to be the theory of a geoecosystem, a universal methodological conception used in describing geographical regions at various scales. It allows the use of quantitative research methods, and hence parameterisation of their environment. Thus, the geoecosystems of basins without outlets can provide foundations of their dynamic classification.
\end{abstract}

Key words: theory of geoecosystem, basins without outlets

\section{Introduction}

Basins without an outlet are a permanent element of a postglacial landscape in the temperate climatic zone. Their catchments occupy a substantial proportion of its area. They greatly influence the water cycle in a river basin since they create special conditions for the circulation of water (Kowalska 1970, 1971). For many years these objects have been of much interest to researchers, including geomorphologists (as landforms), hydrologists (as receptacles in hydrographic units), land reclamation workers (as water management objects), and ecologists (as habitats). These valuable landforms have been examined in a variety of aspects: hydrological, geomorphological, morphometric, hydrochemical, ecological, natural, and agricultural. Attempts have been made to introduce classifications, typologies and terminologies of basins without outlets, and in more recent works various models describing their operation have been proposed. Even so, the body of knowledge about the function those elements perform in the postglacial landscape is still unsatisfactory: especially lacking are works treating them in a systems approach. An interesting approach possible to adopt seems to be the theory of a geoecosystem, which is a universal concep- tion that can be used in a variety of natural sciences. This theory has also found application in geographical sciences, especially in dynamic geomorphology (Kostrzewski 1986, 1993a,b,c, 1995). It encourages the use of new methods of study, offers comparisons with other disciplines, and allows Geographic Information Systems (GIS) to be employed in the research process.

\section{Methodological assumptions}

In Kostrzewski’s (1986) proposal, a geoecosystem is a natural landscape system featuring a constant energy flow and a matter cycle. Thus, the basic properties of a geoecosystem are energy, matter and information (Kostrzewski 1986, 1993a). The chief source of all energy changes in geoecosystems is solar energy, which determines their way of operation and the rate of processes occurring in them. Solar energy sets in motion the flow of energy at a variety of spatial scales; hence each selected geoecosystem has its own energy flow.

There is a chain of energy and matter changes in geoecosystems (Kostrzewski 1986, 1993a), i.e. there is an ongoing transformation of energy and matter dependent on a variety of factors: global (climate change), regional (relief) and local, smaller in extent. 
Potential energy keeps changing into kinetic energy and vice versa, and the changes are accompanied by movements of matter.

While energy is the impulse initiating the matter cycle, the causative factor of the cycle is the circulating water. Matter, which can be organic or inorganic in origin, is the next property of a geoecosystem. It is deposited in the bottoms of depressions. The deposits are a reflection, among other things, of the climatic, hydrological and local conditions obtaining in their catchments from their formation until the present moment, i.e. they are a record of the history of today's landforms. The deposits are also proof of landscape evolution, which means they can help us to understand the development cycle of present-day morphogenetic environments.

An effect of the interaction of energy and matter in a geoecosystem is information (deposits and landforms). The information encoded in a system's memory can be long-term in the case of old objects, and short-term and episodic in the case of young ones. In turn, the time during which information is preserved in a geoecosystem depends on its resistance to external stimuli. A measure of the resistance is the so-called relaxation time, or the time the system needs to revert to the previous state after a stimulus has acted upon it (Kostrzewski, 1986, 1993a). Relaxation time is determined by the system's geographical location, its state, inner structure and resistance, and the effect of the man-made factor.

The point of departure for reflections about a geoecosystem is its current state (Kostrzewski and Zwoliński 1992). The state of a geoecosystem is defined by the combination of energy, matter and information at the moment of observation (Kostrzewski 1993a). The knowledge of the current state of a geoecosystem makes it possible to anticipate the directions of its further development.

The range within which all changes occur in a geoecosystem during a study period is called a range of allowed states. If this range is exceeded, the geoecosystem is threatened with disaster. For each geoecosystem it can be determined in quantitative terms. The nature and size of the range of allowed states depends on the size, type and geographical location of the system.

Within the range of allowed states lies the state of stability. It embraces a specific configuration of states through which a geoecosystem goes in the course of its development (Kostrzewski 1993a). In a state of stability the composition of the geoecosystem is constant despite a continuous exchange of components. States of stability are equifinal, which means that the same, time-independent state can be reached whatever the initial conditions and whatever the ways leading to it (Bertalanffy 1984). The range of stability can be favourable or unfavourable to the state of the environment (Kostrzewski 1986, 1993a). For example, a persistent drought is a detrimental occurrence leading to the lowering of surface- and groundwater levels and in consequence to the disappearance of water, e.g. from kettle ponds located at the bottoms of basins without outlets. But as a short-term, periodic event it does not disturb the internal structure of the geoecosystems of such closed depressions.

\section{The catchment of a closed basin as a geoecosystem}

The proposal of a research on areas without an outlet in a systems approach rests on the conception of a system proposed by Bertalanffy $(1932,1984)$. The methodology of systems research has been confirmed by American (Chorley 1962; Chorley and Kennedy 1971) and Polish works (Kostrzewski 1986, 1993a, b, c, 1995). The use of the term geoecosystem gives the conducted studies an application aspect (Kostrzewski 1993a).

In systems research the basic spatial unit is the catchment (Drwal 1982) because it is easy to assess the flow of energy and the matter cycle within one (Fig. 1). Hence, catchments of hydrographic objects (streams, lakes, wetlands, springs) as well as those of areas without an outlet, are geoecosystems.

In the opinion of e.g. Drwal (1975), the existence of areas without an outlet, i.e. not included in the general drainage system, is determined by climatic factors, relief, and the geological structure. Relief is a factor responsible for the absence of surface outflow, and total lack of outflow is caused by the permeability of surface deposits. Thus, catchments with no surface outflow are open systems determined by matter exchange (Bertalanffy 1984), and those with no outflow whatsoever are closed systems that can receive a steady inflow of energy and matter circulating within them, but their outflow is absent or highly limited, thus leading to their build-up. Kostrzewski (1995) calls catchments with no surface runoff "closed" systems, but research results show that there are practically no closed systems in postglacial areas. Even in the case of evapotranspiration areas without an outlet there occurs 

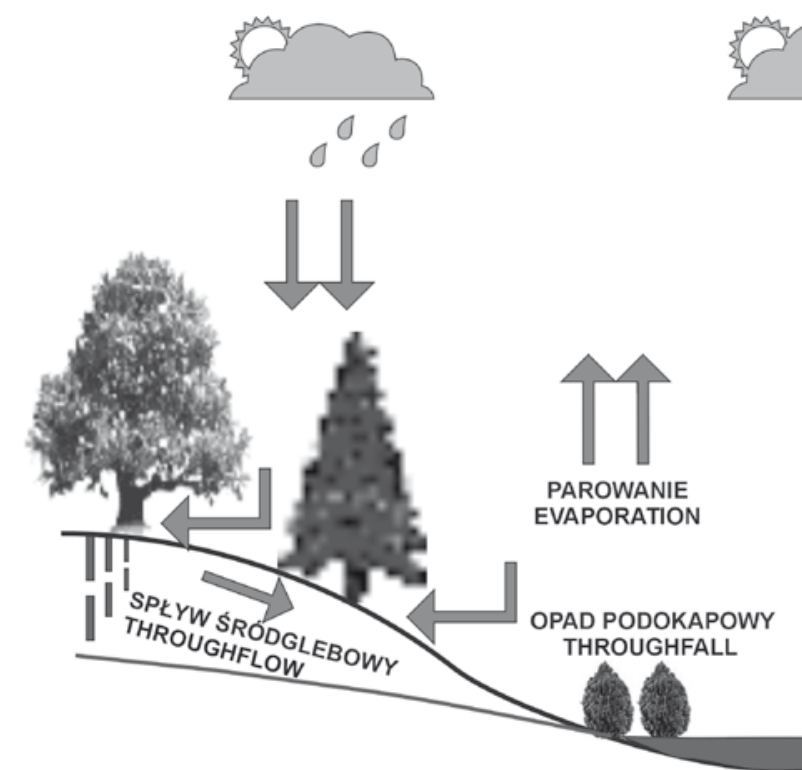

INFILTRACJA INFILTRATION

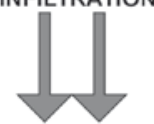

ODPŁYW GRUNTOWY GROUNDWATER FLOW

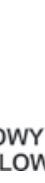

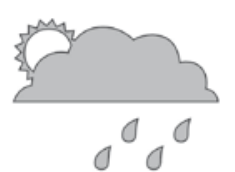

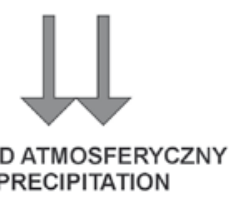
PRECIPITATION

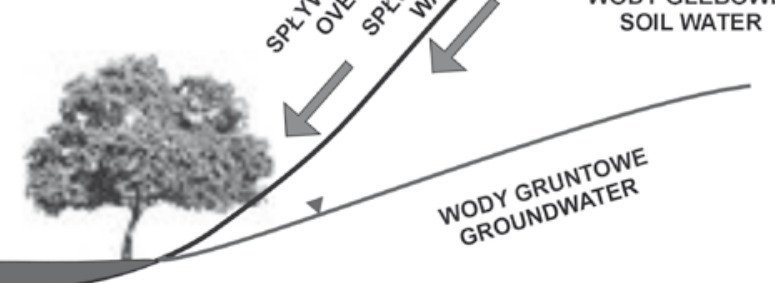

ODY POWIERZCHNIOWE SURFACE WATER

Fig. 1. Simplified model of the water cycle in the catchment of a closed basin (Major 2009)

not only evaporation, but also percolation, which attains a substantial volume. This has been corroborated by water balance studies in the upper Parsęta catchment (Major 2009) and in catchments with no outflow of the Kashubian hydrographic system (Drwal 1982).

Thus, catchments that have no surface outflow of water are concave landforms with a constant inflow of matter supplied primarily from the atmosphere. Matter circulates here together with water (Fig. 1). Precipitation water falls to the surface of a catchment and flows down the slope of the terrain towards a depression where it infiltrates to groundwater either completely (an absorptive type of basin) or partially (an evapotranspiration type).

Hence, all the geoecosystems of basins without outlets are open systems and can be modelled depending on the geographical location and local conditions of a catchment.

The two types of areas without a surface outflow, absorptive and evapotranspiration ones, differ in the mechanism and rate of the circulation of water, which is the carrier of dissolved substances as well as solid particles, both mineral and organic. The amount of water and the time of its circulation determine the rate of supply and transport of dissolved material, usually downslope towards the bottom of a depression that is the receiver (sedimentary basin) of the circulating matter. Temporal variations in the supply and transport depend primarily on weather conditions. The most important controls of the present-day geoecosystems of basins without outlets in the temperate climatic zone are the distribution of atmospheric precipitation and the size of evaporation. Of no little significance is also their relief.

Differences in the "penetration" of matter beyond the geoecosystem of basins without an outlet depend on the permeability of surface deposits. As estimated by Major (2009), between 1999 and 2001 in the upper Parsęta catchment a total of $357 \mathrm{~mm}$ of precipitation water reached groundwater from the geoecosystems of absorptive basins and $350 \mathrm{~mm}$ from evapotranspiration ones.

The geoecosystems of basins without outlets differ in land surface, morphology, lithology, soils, as well as land cover and use. The last two features are very important for their operation. In the postgla- 
cial zone, they are usually located in arable fields and forests, and much less frequently within the limits of various settlement units.

The geoecosystems of basins without outlets have their own characteristic energy flows. Solar energy is either absorbed by all the elements of their internal structure, or changed into work. A measure of potential energy in a geoecosystem is a difference in height. Among the catchments of such basins one can find ones with a small difference in energy levels, i.e. with small differences in relative heights, and ones with a bigger difference in energy levels. In the postglacial landscape, which displays considerable amplitudes of relief, differences in height between the watershed of a catchment and the bottom of a depression can reach about a dozen, or even tens, of metres.

\section{Properties of geoecosystems of basins without outlets}

The causative factor initiating the matter cycle in the catchment of a closed basin is circulating water supplied by atmospheric precipitation (Fig. 1). In areas with no outlet, when we consider matter as one of the properties of their geoecosystem, we also mean deposits accumulated in the bottoms of depressions, which are organic in origin in their top layers and can attain a few hundred centimetres in thickness (Major 2009). Under the organic deposits there is only a mineral substratum. The deposits found in the bottoms of basins without outlets reflect the climatic, hydrological and local conditions obtaining in the catchments under study.

Information is an effect of interaction between energy and matter in the geoecosystem (deposits and forms). With reference to basins without outlets, these are mostly deposits accumulated in the bottoms of depressions and such forms as the various profiles and shapes of slopes around the depressions or other elements of relief. Information decides the current state and external look of the geoecosystem.

Relaxation time in basins without outlets is a measure of the disappearance rate of traces of erosion on their slopes after a violent shower, an equalisation of surface- and groundwater levels after an intensive atmospheric supply, or a rise in groundwater stages after a hydrological drought.

Each catchment of a basin with no outlet has its own range of allowed states. In the case of the eva- potranspiration type of basins, allowed states can range from low-intensity morphogenetic processes (absence of surface waters in the catchment) to highintensity ones (water level close to the watershed one).

\section{Matter cycle in the geoecosystem of a basin without an outlet}

The adoption of the conception of a territorial system makes it possible to estimate the balance of matter in it in quantitative terms.

The results of the research conducted in the upper Parsęta catchment make it possible to present a few regularities occurring during the transformation of precipitation along the vertical atmosphere-lithology-groundwater line in the geoecosystem of a basin without an outlet (Major 2009). In the geoecosystem under study, water mineralisation was calculated as the sum of mean values from the entire measuring cycle (the hydrological years 1999-2001) of all the components considered in the ionic balance at individual stages of the water cycle. Water mineralisation expressed in $\mathrm{mg} \mathrm{dm}^{-3}$, corresponds roughly to specific electrolytic conductivity expressed in $\mu \mathrm{S} \mathrm{cm}^{-1}$.

The lowest mineralisation, at $7.65 \mathrm{mg} \mathrm{dm}^{-3}$, characterised open-terrain precipitation. On contact with the biosphere, the mineralisation of precipitation water increased fivefold in the bottom of the closed basin, and threefold in the western part of its catchment (Fig. 2).

On contact of precipitation water with the pedosphere, the jump in mineralisation was almost 14-fold, and in the top layers of the soil profile, nearly 16 -fold. However, during the percolation of water through the soil profile its mineralisation dropped to $87.18 \mathrm{mg}$ $\mathrm{dm}^{-3}$ (Fig. 2), to rise again in the water-bearing layer.

The mean mineralisation of groundwater amounted to $170.51 \mathrm{mg} \mathrm{dm}^{-3}$ (Fig. 2). The shallowestlying groundwater in the bottom of the basin showed the lowest mean mineralisation, at $123.51 \mathrm{mg} \mathrm{dm}^{-3}$, while the mineralisation level of groundwater sampled from sites located midway on its slopes was almost double, at $217.32 \mathrm{mg} \mathrm{dm}^{-3}$. The highest mineralisation, at $466.27 \mathrm{mg} \mathrm{dm}^{-3}$, was displayed by groundwater near the watershed (Fig. 2).

\section{Discussion}




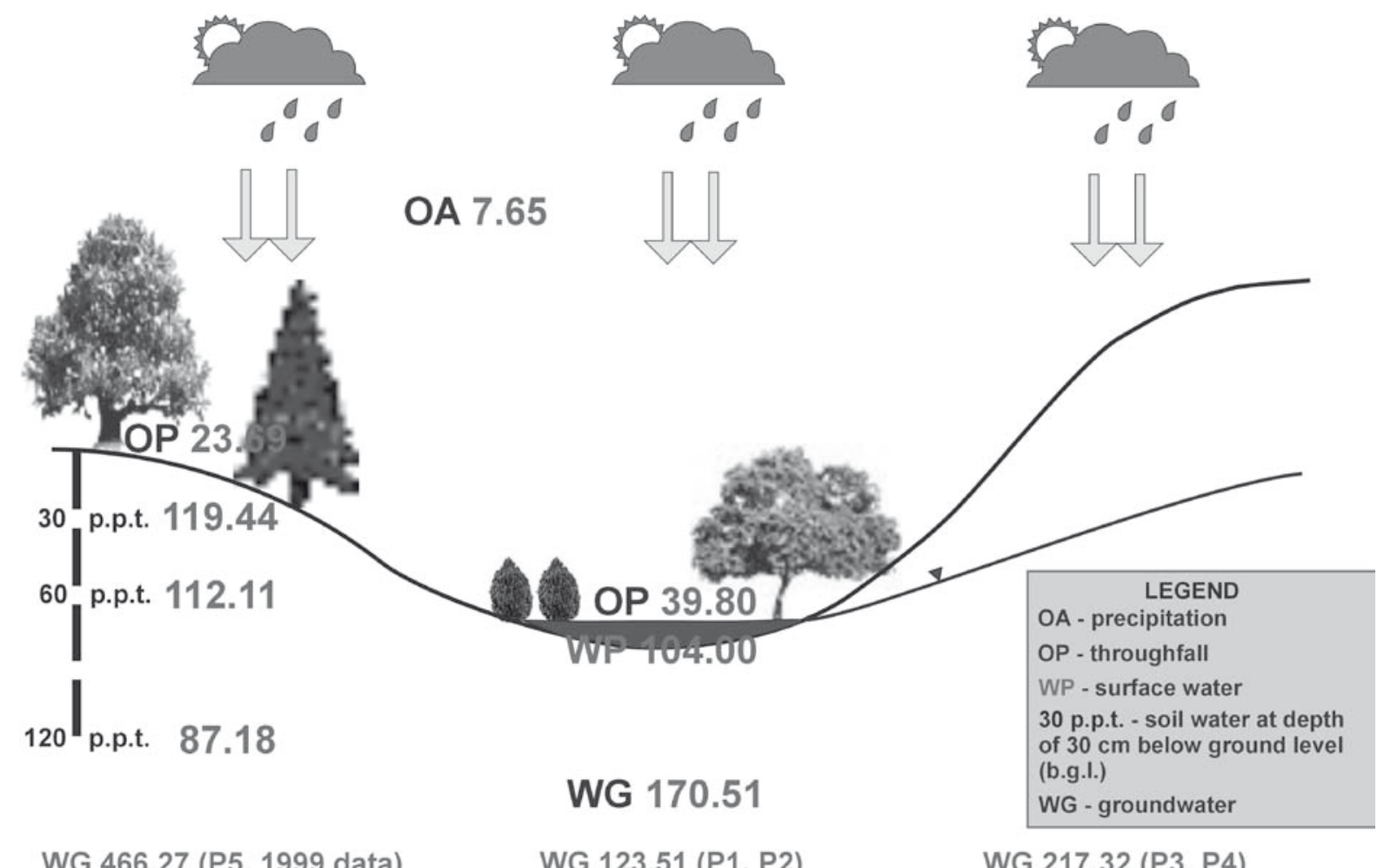

WG 466.27 (P5, 1999 data) WG 123.51 (P1, P2)

WG 217.32 (P3, P4)

Fig. 2. Mineralisation of water (in $\mathrm{mg} \mathrm{dm}^{-3}$ ) at various stages of its circulation in the catchment of a closed basin (Major 2009)

The theory of a geoecosystem (Kostrzewski $1986,1993 a)$ is a methodological conception that can be employed in a study of areas with no outlet at the bottom of which one can often find kettle ponds and small lakes. In their case, an examination of the essence of a "whole" and "wholeness" (Bertalanffy 1984) involves the assumption that depressions with no outlet, as small landforms supplied with matter and energy by their catchments, are geographical environment objects ideal for detailed studies in a systems approach. The conception presented above allows the geographical environment to be parameterised and can be used to work out foundations of a dynamic classification of geoecosystems of basins without outlets.

In the conception of a territorial system, the basic unit is the catchment of a depression without an outlet, or its geoecosystem. In the research, special attention should be paid to sources supplying matter as well as pathways of its circulation and outflow identified after the internal structure of such a catchment has been established.

The theory of a geoecosystem makes possible the application of selected theoretical and mathemati- cal models that can help to determine the current state, role and significance of basins without outlets in present-day agricultural and woodland ecosystems. It also allows anticipation of the directions of further changes in those basins and setting guidelines for their protection.

Under the systems approach, one can not only build theoretical models of the processes shaping physical-geographic systems of ever greater complexity (from simple morphological systems through cascading, dynamic ones to steady-state systems), but also introduce conceptions of how to control and steer those systems.

\section{References}

Bertalanffy L., 1932, Theoretische Biologie: Allgemeine Theorie, Physikochemie, Aufbau und Entwicklung des Organismus, Gebrüder Borntraeger, Berlin, p. 349.

Bertalanffy L., 1984, Ogólna teoria systemów (General System Theory), PWN, Warszawa, p. 339 (in Polish).

Chorley R.J., 1962, Geomorphology and General Systems Theory, U.S. Geol. Surv. Prof. Paper, 500-B: 1-10. 
Chorley R.J., Kennedy B.A., 1971, Physical Geography: A Systems Approach, Prentice Hall, London, p. 370.

Drwal J., 1975, Zagadnienia bezodpływowości na obszarach młodoglacjalnych (Lack-of-outlet issues in postglacial areas), Zesz. Nauk. Wydz. BiNoZ UG, Geografia 3: 7-26 (in Polish, English summary).

Drwal J., 1982, Wykształcenie i organizacja sieci hydrograficznej jako podstawa oceny struktury odpływu na terenach młodoglacjalnych (Formation and organisation of the hydrographic network as a basis of assessment of the structure of runoff in postglacial areas), Zesz. Nauk. UG, Rozpr. Monogr. 33: 1-130 (in Polish, English summary).

Kostrzewski A., 1986, Zastosowanie teorii funkcjonowania geosystemu do badań współczesnych środowisk morfogenetycznych obszarów nizinnych Polski Północno-Zachodniej (Application of the theory of geosystem operation in the research on present-day morphogenetic environments of lowland areas in North-Western Poland), Spraw. PTPN 103: 26-28 (in Polish).

Kostrzewski A. (ed.), 1993a, Geoekosystem obszarów nizinnych (Geoecosystem of lowland areas), Zesz. Nauk. Kom. Nauk „Człowiek i Środowisko” PAN 6: 1-180 (in Polish, English summary).

Kostrzewski A. (ed.), 1993b, Zintegrowany Monitoring Środowiska Przyrodniczego w Polsce. Wybrane problemy (Integrated Monitoring of the Natural Environment in Poland. Selected problems), Biblioteka Monitoringu Środowiska, PIOŚ, Warszawa, p. 225 (in Polish).

Kostrzewski A. (ed.), 1993c, Zintegrowany Monitoring Środowiska Przyrodniczego w Polsce. Propozycje programowe (Integrated Monitoring of the Natural Environment in Poland. Programme proposals), Biblioteka Monitoringu Środowiska, PIOŚ, Warszawa, p. 152 (in Polish).
Kostrzewski A. (ed.), 1995, Zintegrowany Monitoring Środowiska Przyrodniczego w Polsce. Propozycje programowe (Integrated Monitoring of the Natural Environment in Poland. Programme proposals), Biblioteka Monitoringu Środowiska, PIOŚ, Warszawa, p. 152 (in Polish).

Kostrzewski A., Zwoliński Z., 1992, Udział denudacji chemicznej i mechanicznej we współczesnym systemie geomorficznym górnej Parsęty, Pomorze Zachodnie (Contribution of chemical and mechanical denudation to the present-day geomorphic system of the upper Parsęta, West Pomerania), Pr. Geogr. IGiPZ PAN 155: 11-45 (in Polish).

Kowalska A., 1970, Problemy metodyczne wyznaczania obszarów bezodpływowych na Niżu Środkowoeuropejskim (Methodological problems of delimiting areas without an outlet in the Central European Plain), Prz. Geogr. 42(1): 105-111 (in Polish, English summary).

Kowalska A., 1971, Zagadnienie środkowoeuropejskich obszarów bezodpływowych w literaturze (Issues in Central European areas without an outlet in the literature), Czas. Geogr. 42(4): 353-363 (in Polish, English summary).

Major M., 2009, Charakter i funkcjonowanie zagłębień bezodpływowych w krajobrazie strefy młodoglacjalnej (Pomorze Zachodnie, górna Parsęta) (Nature and operation of basins without an outlet in the landscape of a postglacial area: West Pomerania, the upper Parsęta river), PTPN, Poznań, p. 178 (in Polish). 